\title{
Manipulating the Mechanism of Epistemic Vigilance in Political and Legal Discourses
}

\author{
Olga A. Bartashova \\ and Svetlana E. Polyakova* \\ St. Petersburg State University of Economics \\ 21 Sadovaya Str., St. Petersburg, 191023, Russia
}

Received 31.03.2018, received in revised form 14.04.2018, accepted 24.04.2018

To achieve the goal of illocution when communicating one has to tackle particular strategic tasks. Communication and speech strategy means a certain plan on an optimum realization of one's communication intentions. Political speech during elections or advocate defense speech are regarded as persuasive type of texts which actualize strategies and tactics of convincing people of veracity in a particular situation. Within the category of persuasiveness there is a speech manipulation phenomenon which aims modeling the addressee's behavior. It can be oriented on the mechanism of epistemic vigilance - a cognitive process which allows classifying the incoming information as valid or invalid.

Keywords: communication and speech strategy, persuasiveness, manipulation, mechanism of epistemic vigilance, political discourse, legal discourse.

DOI: 10.17516/1997-1370-0263.

Research area: linguistics.

Political and legal discourses are the types of institutional discourse which aims at organizing and managing the social network. These types are mostly represented through pragmatically persuasive texts (electioneers' speeches, parliamentary debates, prosecutor's charges and speeches for the defense, etc.). From a general linguistic perspective persuasiveness means how the addressant influences the addressee by convincing them in something or motivating to certain actions given a free choice perceived by the addressant.

Any discourse is grounded in a certain pattern of human experience. The modern society is characterized by its political engagement: people in each country are becoming more and more interested in policy and politicians' speeches where the language means a powerful tool in achieving political gains. The policy language enjoys a pragmatic nature since language and actions are interconnected in policy. Many linguists admit that the persuasive function dominates in the political discourse (A.P. Chudinov, Ye.I. Sheigal, et others). Political communication aims first and foremost a race for power, since the last, in turn, is conventionally recognized as a social value - in this fight politicians make use of political texts of a

(C) Siberian Federal University. All rights reserved

* Corresponding author E-mail address: o_bartashova@mail.ru; poliakova2106@mail.ru 
great illocutionary capacity. That is way when analyzing political communication we can't but notice their high professionalism or artistic deficit, as well as communicative failures or successes (Chudinov, 2013: 8). The redactors of persuasive political texts use different forms of linguistic manipulation: from an ideological totalitarian direct linguistic violence to a veiled manipulation (Litovchenko, 2003: 4).

A speech for the defense and prosecutor's charges are also regarded as persuasive texts where the defense attorney or prosecutor pursues a strategy to convince the court and the audience in the veracity of their statements towards the lawsuit through informing, interpreting, proving and rebutting.

One feature of persuasive speech action is speech manipulation, i.e. an implicit linguistic effect on the addressee intended to model their behavior in an advantage for the manipulator. Linguistic manipulation is basically characterized by its implicitness and by the fact that such enforced behavior does not match the object's real desires. Thus, V.P. Sheinov sees manipulation as "an implicit control over a person against their will that gives the manipulator unilateral advantages", i.e. when the addressant's intentions, conflicting with the addressee's will, are latently implanted into the addressee's mind. When manipulating, the addressant is out to persuade the object to trust certain words not relying on evidences. In this way, the addressee often fails to feel this intent to control their behavior or consciousness (Sheinov, 2001: 4).

To succeed in any manipulative intention, the manipulator plays with the information (using such techniques as aposiopesis, selection, misrepresentation, inversion, etc.), logic content (invidious analogies, complex equivalence, presetting nominations, subject shifts, etc.) and stylistic framework (Bartashova, et al., 2017). Manipulation can also be focused on the addressee's epistemic vigilance. The latter, in turn, means a crucial communicative cognitive mechanism which allows classifying the incoming information as valid or invalid.

\section{Theoretical framework}

In the modern linguistics, the most prominent investigation of epistemic vigilance is the one made by D. Sperber (Sperber, et al., 2010).

Human interaction is cannot do without communication system and language, that enable people to share information, which might be considered as a means of knowledge acquisition. As such, it is also able to reflect "just the process of cognition" (Klepikova, 2009: 57), i.e. it records the reflection that emerges in both cognitive units subject and object. Monitoring and assessment of self and addressee's consciousness are metacognitive processes. Metacognition is considered as a human ability to represent self-consciousness, memory, imagination and the same content of the person you are communicating with (Sperber, 2000). Thus, metacognitive processes maintain communicative performance and stand by its interactive aspects such as a dynamic modeling process of the interlocutor's mental content, monitoring over the interlocutor's mental state, further correction of self-speech behavior, bilateral comprehension control (Klepikova, 2011: 60).

When communicating, a person may face the risk of being given false and misleading information that can damage him or any third party. In this way, to preserve the efficiency of communication, a defense mechanism is needed, s.s. epistemic vigilance (Sperber, et al., 2010).

The term epistemic vigilance is regarded as a set of cognitive mechanisms which indexes the incoming information as valid/invalid information, i.e. a sign of trust/distrust towards the interlocutor.

Linguistically the mechanism of epistemic vigilance can be evident through such markers 
as: "allegedly", "oh?/ain't that right?", "they say", "seriously?"; or idiomatic units as: "to take at its face value", "to string a line", etc.

It is the risk of being cheated in communication that identifies epistemic vigilance as an essential part of interaction, thus, the information validity is being permanently assessed by the participants.

In assessing the incoming information, the greatest importance is given to two parameters: source and content. As for the first, the dynamics of epistemic vigilance (i.e. increase/decrease in trust to the utterance) depends on the speaker's competence, on his willingness/unwillingness to share the information, presence/absence of "credibility" and good reputation and on the emotional state. In the second case epistemic vigilance is determined through information relevance/irrelevance, adequacy/inadequacy with the listener's background and expectations (Klepikova, 2011).

So that, regarding the information source epistemic vigilance decreases (thus, increasing the degree of trust) provided that the source is competent and the information is obtained through reliable channels (e.g. being a witness and speaking about such experience). If these conditions are not met, one may observe a reverse process - increasing epistemic vigilance and decreasing trust.

Concerning the information source, epistemic vigilance decreases given irrelevant information which matches the listener's expectations and background knowledge. In other case, i.e. if the information appears to be inadequate for the listener, their confidence declines.

Moreover, the dynamics of epistemic vigilance is likely to be significantly influenced by the utterance form as well: particularly, by such parameters as stylistically marked messages, implications/explications, tempo, intonation, syntax and non-verbal markers (mimics, gestures, etc.) (Klepikova, 2011: 63). In this way, epistemic vigilance may well be increased/decreased by applying both linguistic and extra-linguistic devices.

Working with the utterance form and content, the addressant can enhance credibility of their statement or distrust in third parties' performance, thus, manipulating the recipient. Therefore, the mechanism of epistemic vigilance supports persuasive strategy as the leading communicative and speech technique for certain types of texts.

\section{Approaches in manipulating the epistemic vigilance mechanism in political discourse}

In a general observation of what can be defined as the policy language (most commonly "specific language system designed for political communication: for reaching a social consensus, making and supporting political and sociopolitical decisions" (Afanasenko, 2006: 12) it is characterized by "its availability for understanding by almost all the members of linguistic community due to de-specialization of political terminology" (Sheigal, 2000: 20). This means that the texts in political discourse can be produced and perceived not only by politicians, but also by people without any knowledge in political studies.

Let us consider the mechanism of epistemic vigilance through the speeches by one of the most remarkable politicians of these days - D. Trump.

As it has been mentioned above, the dynamics of epistemic vigilance can be affected by such parameters as the message's source, content and form.

Concerning the source of information, a politician needs to gain the audience's trust and win them round. To achieve this goal, it is necessary to appear as a robust information 
channel ("I've seen/heard"), since trust can be inspired by competent people - the ones who are well-informed of the considered problem.

Thus, Mr. Trump uses such device as appealing to emotions by relying on his personal stories. However, if he employed statistics or figures, the audience's attention would be distracted as it would not meet its background experience. Still, such personal, subjective and emotional factor has a great impact on people decreasing their epistemic vigilance. Describing the situation with Mexican emigration, D. Trump emphasizes that he has personally visited the Mexican border and spoken to the border forces - so, he is that source of information delivered to the journalist:

Journalist: What evidence do you have specific evidence - that the Mexican government is sending criminals across the border?

Trump: Border patrol - I was at the border last week. Border patrol, people that I dealt with, that I talked to, they say, "This is what's happening."

Another manipulation tactics used by D. Trump in terms of the source of information social approval (the majority's acknowledgment) actualized through a generalizing pronoun everybody - that results, on the one hand, in a high degree of confidence in the information provided and, on the other - a situation when one fails to verify this information:

And everybody said I won at the debate, and everybody said I won all six debates, and especially the last one, so everybody said I won that debate.

This statement may result in both either decreased or increased dynamics of epistemic vigilance depending on the recipient's background knowledge and psychotype; but the repetition used in this statement has a high persuasive potential and lulls the audience. Right in the next sentence D. Trump ensures a higher degree of credibility and objectivity in the information source through every online poll:

Every online poll said I won every one of the debates, especially the last one.

Such persuasive device excludes any doubts among people and increases their confidence in the source, thus, declining their epistemic vigilance.

Regarding the parameter of content of statement, the most common approach focused on epistemic vigilance lowering is the implementation of irrelevant information which does not refer to the matter in point.

Speaking on the illegal Mexican immigrants, the politician exaggerates: the threat posed by the unauthorized immigrants - thieves, drug dealers and abusers - is presented as terrorism that, in turn, provokes fear which keeps the majority of people from responding adequately to the incoming information. Such irrelevant content technically matches the recipients' background and, consequently, decreases the dynamics of epistemic vigilance:

"I love the Mexican people ... I respect Mexico ... but the problem we have is that their leaders are much sharper, smarter and more cunning than our leaders, and they're killing us at the border."

At the same time, he falls back on inversion highlighting his respect to the Mexicans and shifting the emanating threat on the Mexican government.

A supporting strategy lies in his turn to negative emotions which also push fear and hate and sidetrack the internal social problem of employment: 
"They're taking our jobs. They're taking our manufacturing jobs. They're taking our money. They're killing us."

We shall note that these manipulations appear naturally: the audience does not control their emotions under such suggestive persuasive influence. The impressed information has little relation to the core problems of American society that, in fact, should be brought into light by the promotees. The mechanism of epistemic vigilance works in such a way that being driven by negative emotions, epistemic vigilance lowers against the backdrop of increased credibility to D. Trump's statements. Irrelevant information steals the basic discussion and, thus, the addressant fulfils their communication task - to avoid the discussion.

Considering the form of utterances, it is worth noting, that one of the most crucial means used by D. Trump which influence epistemic vigilance are numerous repetitions that seem to "hypnotize" the listener and result in lower epistemic vigilance. This device may rather be considered as suggestion than persuasiveness. The difference between them is an implicit nature of the first one and its reliance on the recipient's feelings and associations and lack of control over emotions. However, this strategy may be observed through persuasiveness since it means not only a convincement backed with rationality, but some expressive means of manipulation as well:

"When they called me today they were so apologetic. They called me up this morning, they were so apologetic. When they called me this morning, they were apologizing;

We need the toughness. We need strength.

We need strength. We need tough people. We need toughness.

We have to be much stronger than we've been.

You're a tough guy, Jeb, I know'.
We can't but mentioned D. Trump's brilliant skill to maintain the dynamic of epistemic vigilance mechanism towards its decrease not only among the voters, but among the counterparts as well. To reach this target he frequently uses an informally-friendly appeal to his opponent enriching the form with a positive connotation: You're a tough guy, Jeb, I know. Thus, on the one hand, there is another decrease in the opponent's epistemic vigilance, as he, although ironically, is called "a tough guy"; on the other one can find increased epistemic vigilance towards G. Bush's words, since the audience is sure that Mr. Bush (D. Trump's opponent) is a prudent politician who cannot be called that way. Thus, one and the same speech device may simultaneously change the dynamics of epistemic vigilance in different vectors.

The use of repetitions intensified with sequential negative constructions points out an unquestionable nature of D. Trump's statements that the country suffers the crisis a presupposition to faithfully perceive the final fact that if he runs this country, it will tackle the current situation:

"We don't win any more. We don't win any more in our country, Shawn. We don't win any more. We used to win. We don't win any more. We don't win with trade. We don't win with war. We can't even beat ISIS, and we're going to win. If I win, I will tell you, if I win, we all win because we are going to win".

The dynamics of epistemic vigilance may also be changed through the means of other semiotic systems. Non-verbal tools used by D. Trump seem to be a natural habit of him, but, indeed, they not just simplify the process of communication, but also have a power of suggestive-persuasive influence, since they allow dealing with his interlocutors and emphasizing the essence of his speeches. 
As so, the ones which can decrease the audience's epistemic vigilance include such gesture as $\mathrm{O}$ made with one's palm and fingers which then slowly turns into $\mathrm{L}$ - one of the most commonly used by D. Trump. It demonstrates a certain image of logic in revealing his idea and, thus, should generate the audience's trust towards the information. Moreover, perceiving the information as relevant may be supported by "thumb up" gesture that focuses the listener's attention on a moment which is important for Mr. Trump and, thus, dare to be noticed by the voters as well. Another gesture to be mentioned is his palm forward - it draws the attention to something one should be warned about - usually followed by an argument which convinces the listener that $\mathrm{D}$. Trump will manage this problem. Such gestures provide increasing trust towards the speaker's words and decreasing epistemic vigilance among people.

Increased epistemic vigilance to the counterpart's words can be exemplified through the way Mr. Trump ignores his rival not paying any attention to him and accompanying his statements with "disrespect" mimics or with much tricky questions. Stylistically such question answered by the addressant per se is similar to a tag question, with the only difference that the last one should be answered by the addressee, and if the addressant responds to such question - they do it for their own advantage:

Trump: You're not talking, you interrupted me, Jeb. Are you apologizing? Jeb? No.

\section{Approaches in manipulating the epistemic vigilance mechanism in legal discourse}

Manipulating the mechanism of epistemic vigilance in legal discourse most easily may be exemplified through speeches for the defense delivered by lawyers. Playing with the dynamics of epistemic vigilance, the lawyer can act in two directions: to decrease the audience's epistemic vigilance towards his/her words or increase the one towards the prosecutor's speech or state evidences.

In the final speech the lawyer tries to deliberately influence the addressee (judge or juries) in order to decrease their epistemic vigilance.

As for the source of statement, the lawyer has to demonstrate his/her competence in the lawsuit: it may be done by claiming that he/she has such experience and, thus, may be recognized as a valid information source. In this way, advocating a doctor who treated his patient with the medicine which had not been approved by the FDA, he emphasizes the fact that he is susceptible to a serious disease himself and has a clear idea about its symptoms - thus, demonstrating his competence. Still, it remains impossible to verify this experience, so the lawyer may well lie to achieve his goal, to inspire confidence. He also represents himself as "us" - people who suffer from serious diseases and have to even take some drugs. The fact that this medicine is prohibited is not denied, so as it also contributes the audience's trust:

"I'm at risk for Alzheimer's.... What you wouldn't know is what it feels like to be. There's a prescription drug dextroamphetamine. It's very big on the black market. ...Idon'tknowhowitworks. But you get your memory back".

Personal knowledge of the defendant allows the lawyer to judge him as a law-abiding man and, thus, doubt the prosecutor's claims for a perjury:

"Jerry Espenson is my friend. I care for him... dearly. And I know him to be fundamentally, a law-abiding man, who simply saw an injustice and tried to do something about it". 
To decrease the audience's epistemic vigilance the lawyer often refers to some researches hiding behind scientific credibility:

"Scientists say the average American has about 10 units of Dioxin in their blood fat;

A recent poll showed that the more people watch this news show, the less they know about foreign policy;

Researchers estimate that smoking in movies delivers nearly four hundred thousand new adolescent smokers every year".

Persuasive nature of such speech for the defense is underlined by the fact that one cannot verify the set out information.

In the sense of content, the leading device aimed at epistemic vigilance decreasing is implementation of irrelevant information which does not refer to the suit under consideration. In the proceeding such technique is designed mainly for the juries and people in the courtroom (recognized as the ones who are highly subjected to manipulation from the lawyer, since they do not have some specific legal training). Advocating the teacher who was fired for the initiative to introduce creationism into the curriculum, the lawyer turns to the problems in healthcare and policy:

"Attorney Daniel Gellman: The government has systematically distorted or worse, suppressed findings by the FDA and EPA when it comes to contraception, stem cell research. AIDS, global warming, pollution...”

A neutral government being in the midst of such negative lexis as distorted, worse, suppressed necessarily obtains a negative connotation, so that the lawyer expresses his attitude to the government at the same time imposing it on the audience.

The prosecuting party and the judge, as a rule, trace such persuasive device of digression and mark it by a notice of opposition or comment:

- Let's just stick to the case, Counsel, and leave politics out of it.

- You're off the point.

Regarding the form of statement, to decrease the addressee's epistemic vigilance, the lawyers rely heavily on the strategy which creates obviousness and evidence using such linguistic markers as certainly, of course, frankly, apparently, evidently, obviously, no doubt, sure as hell; or lexis: fact, reality and truth" (e.g. in fact, the reality is..., the truth is..., that is just the truth, the truth be told), which presuppose the veracity of proposition and provide increasing trust towards the lawyer's words. When decreasing the audience's epistemic vigilance, one may also turn to such constructions of common knowledge as: Everybody in this room knows...; We all know what happened here; It is well-known; I'm sure you know this;... as you well know. Their persuasive potential reveals when the lawyer instills the listeners such ideas as "if everybody knows, so I should trust" and "if everybody knows, so I should be ashamed of not knowing that".

Another device which has gained particular attention of the lawyers is tag questions which may be obviously answered by the question's main sentence. They know that it is hard not to agree with such questions, since, naturally, such syntactic units are not recognized as question per se, so they do not require any respond:

"That would explain why Warren was trying to flee, wouldn't it?"

"It can't be a straight negligence thing, can it?"

\section{Conclusion}

The speaker's metacognitive process of controlling consciousness - their own and the 
addressee's as well - allow switching on the mechanism of epistemic vigilance that provides monitoring and mainstreaming speech situations and realizing one's communication intentions in the most preferable way.

Manipulation of the epistemic vigilance mechanism used by politicians and lawyers involves influence on its dynamics: decreasing the audience's epistemic vigilance towards one's speech or increasing the one to the opponent. The last goals may be achieved when demonstrating the fact that the addressant is a competent and experienced person, emotionally stable and relevant communication medium; also through implementation of irrelevant information and use of parenthetic constructions of evidence or obviousness and tag questions; practice of attention-grabbing gestures, mimics and speech tempo. On the other hand, epistemic vigilance may be well increased by abjection of one's opponent when pointing out their disadvantages or by creation of alternative scenario of development.

\section{References}

Afanasenko, Ye.V. (2006). Semanticheskii povtor v politicheskom diskurse: na materiale russkogo i angliiskogo iazykov. Dis. ... kand. filol. nauk: 10.02.19. [Semantic Repetition in Political Discourse: exemplified through Russian and English. Thesis for Candidate Degree in Philology: 10.02.19]. Saratov.

Bartashova, O.A., Polyakova, S.Ye., Kiselyova, S.V. (2017). Uchebnoie posobie po logike i teorii argumentatsii [Guide in Logics and Argumentation Theory]. Saint-Petersburg, Izdatelstvo SPbSUE.

Boston Legal (Series). Available at: www.boston-legal.org

Chudinov, A.P. (2013). Ocherki po sovremennoi politicheskoi metaforologii: Monografiia [Essays on Modern Metaphorology: monograph]. Yekaterinburg, Uralskiy gosudarstvenniy pedagogicheskiy universitet, $176 \mathrm{p}$.

CNN. Available at: http://edition.cnn.com/

FNN: Donald Trump's \#StandWithTrumpAZ Phoenix Speech. Available at: https://www.youtube. com/watch?v=rDtvk9GRrpQ

FoxNews. Available at: http://www.foxnews.com/

Klepikova, T.A. (2009). Lingvisticheskie metareprezentatsii kak sposob ob'ektivatsii metakognitivnykh protsessov [Linguistic Metarepresentations as the Way to Objectify Metacognitive Processes], In Kognitivnie issledovaniia iazyka Vypusk V: Issledovanie poznavatel'nykh protsessov v iazyke: sbornik nauchnykh trudov [Cognitive Studies of Language. Issue 5: Investigation of Cognitive Processes in Language. Collection of Research Papers]. Moscow, Tambov.

Klepikova, T.A. (2011). Kategorizatsiia interaktsional'nosti v iazyke: epistemicheskaia bditel'nost' [Linguistic Categorization of Interactionism: epistemic vigilance], In Kognitivnye issledovaniia iazyka. Vypusk VIII. Vzaimodeistvie kognitivnykh i iazykovykh struktur: Materialy Kruglogo Stola v Institute Iazykoznaniia RAN, 1 noiabria 2011 [Cognitive Studies of Language. Issue 8: Interaction Between Cognitive and Linguistic Structures: Roundtable Proceedings. Institute of Linguistics at the Russian Academy of Science on November 1, 2011]. Moscow, Institut iazykoznaniia RAN; Tambov: Izdatel'skii dom TGU im. G.R. Derzhavina.

Kopnina, G.A. (2010). Rechevoe manipulirovanie: uchebnoe posobie [Speech Manipulation: study guide]. Moscow, Flinta, Nauka, 176 p.

Litovchenko, M.A. (2003). Pragmaticheskie osobennosti verbal'noi ataki v politicheskom diskurse (na materiale nemetskogo iazyka). Avtoref. diss. ... kand. filol. nauk: 10.02.04. [Pragmatic 
Features of Verbal Attack in Political Discourse (exemplified through German). Extended Abstract of Thesis for Candidate Degree in Philology: 10.02.04]. Tambov, 26 p.

Republican Presidential Candidate Donald Trump Arrives for a Campaign Event in Phoenix, Arizona on July 11, 2015. Available at: https://www.youtube.com/watch?v=5NREzxY7rWA

Sheigal, Ye.I. (2000). Semiotika politicheskogo diskursa. Dissertatsiia doktora philologicheskikh nauk: 10.02.01 [Semiotics of Political Discourse. Thesis for Doctor Degree in Philology: 10.02.01]. Volgograd, $175 \mathrm{p}$.

Sheinov, V.P. (2001). Skrytoe upravlenie chelovekom (Psikhologiia manipulirovaniia) [Implicit Manipulation (Psychology of Manipulation)]. Moscow, Izdatelstvo AST; Minsk, Harvest.

Sperber, D. (2000). Metarepresentations in an Evolutionary Perspective, In Metarepresentations: A Multidisciplinary Perspective. Oxford, N.-Y. et al: Oxford University Press.

Sperber, D., Clement, F., Heintz, C., Mascar, O., et al. (2010). Epistemic Vigilance, In Mind and Language. 25, (4).

\title{
Манипулирование механизмом эпистемической бдительности \\ В политическом и юридическом дискурсах
}

\author{
О.А. Барташова, С.Е. Полякова \\ Санкт-Петербургский государственный \\ экономический университет \\ Россия, 191023, Санкт-Петербург, ул. Садовая, 21
}

\begin{abstract}
Для достижения той или иной цели в коммуникации необходимо решить конкретные стратегические задачи. Коммуникативно-речевая стратегия представляет собой план по оптимальному осуществлению коммуникативного намерения. Речь политического деятеля на выборах или речь адвоката в суде представляет собой персуазивный текст, в котором реализуется стратегия и тактики убеждения аудитории в истинности занимаемой позиции. В рамках персуазивности выделяется феномен речевого манипулирования, целью которого является моделирование поведения адресата. Манипулятивное воздействие может быть направлено на механизм эпистемической бдительности адресата - когнитивный механизм, позволяюший разграничивать поступающую информацию на валидную и невалидную.
\end{abstract}

Ключевые слова: коммуникативно-речевая стратегия, персуазивность, манипулятивное воздействие, механизм эпистемической бдительности, политический дискурс, юридический дискурс.

Научная спещиальность: 10.02.00 - лингвистика. 